\title{
STUDI SEKUESTRASI KARBON PADA TEGAKAN JATI (Tectona grandis Linn.) DI AREAL PENGHIJAUAN KABUPATEN SORONG
}

\author{
Azis Maruapey ${ }^{1}$, Irnawati ${ }^{2}$ \\ ${ }^{1}$ Universitas Muhammadiyah Sorong \\ Azis.maruapey74@gmail.com \\ ${ }^{2}$ Universitas Muhammadiyah Sorong \\ irnawatif@gmail.com
}

\begin{abstract}
Abstrak
Penelitian ini bertujuan adalah untuk mengetahui biomassa pada tegakan Jati (Tectona grandis L.) di Areal Penghijauan Kabupaten Sorong; untuk mengetahui sekuestrasi karbon pada tegakan Jati; danuUntuk mengetahui sekuestrasi karbondioksida $\left(\mathrm{CO}_{2}\right)$ pada tegakan Jati. Metode yang dipergunakan adalah metode petak tunggal. Penentuan areal lokasi penelitian dilakukan dengan menggunakan teknik purposive sampling. Metode ini merupakan metode penentuan lokasi penelitian secara sengahja dengan mempertimbangkan petak ukur yang dibuat terdapat jenis tegakan Jati. Pengambilan data dilakukan dengan menggunakan metode petak tunggal dengan ukuran $20 \mathrm{~m}$ x $20 \mathrm{~m}$ (Fachrul, 2007). Dalam penelitian ini, untuk menghitung biomassa dalam kaitannya dengan estimasi sekuestrasi karbon pada tegakan Jati dilakukan melalui sampling tanpa pemanenan secara in situ yaitu dengan cara sampling melalui pengkukuran tanpa melakukan pemanenan. Metode dilakukan dengan mengukur diameter atau tinggi pohon dan menggunakan persamaan alometrik untuk mengekstrapolasi biomassa dan estimasi sekuestrasi karbon. Nilai dari potensi biomassa yang terkandung pada tegakan Jati menunjukkan bahwa berat biomassa dari hasil perhitungan 5 petak pengamatan (luasan 0,2 ha) adalah $26.161,13$ g. Sehingga untuk mengetahui berat biomassa dalam luasan satu hektar maka hasil dari perhitungan setiap plot dikalikan lima, dengan asumsi ratarata jumlah tegakan Jati sebanyak 1.100 tegakan per hektar maka jumlah biomassa yang terkandung dalam tegakan pohon Jati adalah sebesar 130.805,65 g/ha. Estimasi sekuestrasi karbon pada tegakan Jati berjumlah 12.295,73 g, sekuestrasi karbon tertinggi terdapat pada plot atau petak pengamatan III yaitu sebesar 3.593,15 dan terendah pada petak IV yaitu sebesar $1.714,41$. Jumlah karbon yang terkandung pada tegakan Jati sebesar 61.478,65 g/ha hasil ini diperoleh dari jumlah karbon pada setiap plot contoh dikalikan lima karena ukuran plot pengamatan hanya seluas $20 \times 20 \mathrm{~m}^{2}$ sebanyak 5 petak. Jumlah sekuestrasi karbondioksida yang tersimpan pada tegakan pohon Jati adalah sebesar 12.295,73 g, dengan demikian maka tegakan Jati mempunyai potensi serapan karbondioksida sebesar 45.125,33 g atau 225.626,65 g/hektar.
\end{abstract}

Kata kunci : Sekuestrasi, Karbon. Tegakan Jati

\section{PENDAHULUAN}

Perubahan iklim global yang terjadi akhir-akhir ini disebabkan karena terganggunya keseimbangan energi antara bumi dan atmosfir. Keseimbangan tersebut dipengaruhi antara lain oleh peningkatan gas-gas asam arang atau karbondioksida $\left(\mathrm{CO}_{2}\right)$. Vegetasi dapat mengubah $\mathrm{CO}_{2}$ menjadi $\mathrm{O}_{2}$ melalui proses fotosintesis.

Vegetasi pohon memiliki komponen biomassa di atas dan di bawah permukaan tanah tetapi komponen biomassa terbesar terdapat pada atas permukaan tanah. Karbon 
merupakan suatu unsur berbentuk padat maupun cair yang biasanya banyak terdapat di dalam perut bumi, di dalam tumbuhan maupun di udara (atmosfer) dalam bentuk gas. Penyimpanan karbon tumbuhan pada bagian atas pemukaan tanah lebih besar dibandingkan bagian bawah permukaan tanah, tetapi jumlah karbon di atas pemukaan tanah tetap ditentukan oleh besarnya jumlah karbon di bawah permukaan tanah. Hal ini terkait dengan kondisi kesuburan tanah (Hairiah \& Rahayu 2007). Karbon memiliki peran penting dalam proses fotosintesis. Proses ini menyerap $\mathrm{CO}_{2}$ dan menghasilkan $\mathrm{C}_{6} \mathrm{H}_{12} \mathrm{O}_{6}$ berikut $\mathrm{O}_{2}$ yang sangat bermanfaat sebagai kebutuhan dasar makhluk hidup (CIFOR, 2008).

Pohon menyimpan karbon diseluruh bagian tubuhnya. Penyimpanan karbon dalam tumbuhan atau pohon meliputi biomassa pohon, biomassa tumbuhan bawah, massa dari bagian pohon yang sudah mati (nekromassa) dan serasah. Hutan alami yang keanekaragaman spesiesnya tinggi dengan serasah melimpah merupakan gudang penyimpanan karbon yang baik (Hairiah \& Rahayu 2007). Hairiah et al. (2001) menjelaskan bahwa jenis vegetasi pada penggunaan lahan sangat mempengaruhi banyaknya karbon tersimpan. Lusiana et al. (2005) menjelaskan beberapa cara untuk menaikkan penyerapan karbon (stok karbon), yaitu dengan menjaga hutan agar dapat tumbuh secara alami, mengurangi pemanenan hutan, menambah jumlah pohon di dalam hutan serta mendirikan hutan tanaman yang pertumbuhannya cepat.

Proses penurunan tingkat emisi karbondioksida $\left(\mathrm{CO}_{2}\right)$ di atmosfer adalah melalui penyerapan oleh tegakan atau vegatasi dalam hutan. $\mathrm{CO}_{2}$ di atmosfer dapat diserap oleh tegakan pohon melalui fotosistesis, tegakan pohon berfungsi sebagai tempat penimbunan karbon yang disebut rosot karbon. Proses penyimpanan karbon dalam tegakan pohon yang dinamakan sebagai sekuestrasi karbon (carbon sequestration), dimana jumlah karbon yang disimpan dalam suatu tegakan sangat bergantung pada jenis dan sifat dari tegakan itu sendiri.

Indonesia termasuk negara dengan luas hutan mencapai jutaan hektar dan beriklim tropis, kondisi ini sangat potensial untuk pengembangan tanaman Jati. Tegakan pohon Jati pada kegiatan penghijauan di Areal Penghijauan Kabupaten Sorong mempunyai kondisi pertumbuhan sangat baik, yang tentunya mempunyai biomassa yang besar dan dapat menyerap karbon yang cukup besar, sehingga sangat perlu dilakukan penelitian untuk mengetahui biomassa, seskuetrasi karbon dan karbondioksida pada tegakan jati di Areal Penghijauan Kabupaten Sorong.

\section{METODE PENELITIAN}

\section{Tempat dan Waktu Penelitian}

Penelitian ini dilakukan di Areal Penghijauan Kabupaten Sorong. Pelaksanaanya akan dimulai dari bulan Juli hingga Agustus 2018.

\section{Bahan dan Peralatan}

Bahan yang menjadi objek penelitian adalah jenis tegakan Jati (Tectona grandis L.) di Areal Penghijauan Kabupaten Sorong. Objek tegakan Jati ini akan dianalisis berdasarkan biomassa per ukuran diameter pohon, biomassa persatuan luas petak pengamatan, dan estimasi sekuestrasi karbon tersimpan pada tegakan Jati. Sedangkan peralatan yang dipergunakan meliputi Clinometer, pita ukur diameter pohon, tali, parang, kamera untuk dokumentasi, tally sheet, dan alat tulis menulis. 


\section{Metode Penelitian}

Metode yang dipergunakan dalam penelitian ini adalah metode petak tunggal. Penentuan areal lokasi penelitian dilakukan dengan menggunakan teknik purposive sampling. Metode ini merupakan metode penentuan lokasi penelitian secara sengaja dengan mempertimbangkan petak ukur yang dibuat terdapat jenis tegakan Jati (Tectona grandis L.). Pengambilan data pada areal penelitian dilakukan dengan menggunakan metode petak tunggal dengan ukuran $20 \mathrm{~m}$ x $20 \mathrm{~m}$ (Fachrul, 2007).

Terkait dengan metode diatas, terdapat 4 cara utama untuk menghitung biomassa terkait dengan estimasi sekuestrasi karbon yaitu (i) sampling dengan pemanenan (Destructive sampling) secara in situ; (ii) sampling tanpa pemanenan (Non-destructive sampling) dengan data pendataan hutan secara in situ; (iii) Pendugaan melalui penginderaan jauh; dan (iv) pembuatan model.

Dalam penelitian ini, untuk menghitung biomassa dalam kaitannya dengan estimasi sekuestrasi karbon pada tegakan Jati dilakukan melalui sampling tanpa pemanenan secara in situ yaitu metode ini merupakan cara sampling dengan melakukan pengkukuran tanpa melakukan pemanenan. Metode ini antara lain dilakukan dengan mengukur diameter atau tinggi pohon dan menggunakan persamaan alometrik untuk mengekstrapolasi biomassa dan estimasi sekuestrasi karbon.

\section{Prosedur dan Pengambilan Data}

Adapun prosedur dalam penelitian ini adalah Pembuatan plot/petak pengamatan sesuai dengan metode penelitian. Dengan menggunakan tali rafia, dibuat beberapa plot/petak pengamatan bentuk bujur sangkar dengan ukuran 20 x $20 \mathrm{~m}$ yang tersebar pada areal penghijauan tegakan Jati (Tectona grandis L.). Semua tegakan Jati yang ada pada setiap plot/petak pengamatan yang meliputi diameter dan tinggi akan dicatat pada buku pencatatan data (tally sheet). Pengukuran adalah, pita pengukuran diameter dililitkan pada batang pohon dengan posisi pita harus sejajar untuk semua arah, sehingga data yang diperoleh adalah lingkar/lilit batang (keliling batang $=2 \pi \mathrm{r}$ ). Untuk mengukur dbh, data yang diperoleh adalah diameter pohon.

\section{Analisis Data}

Data yang diperoleh kemudian diolah secara tabulasi dengan menggunakan persamaan allometrik dalam mengestimasi sekuestrasi karbon tersimpan pada tegakan Jati. Penggunaan persamaan allometrik tersebut dapat digunakan berdasarkan tahapan berikut :

1. Tinggi dan Diamater Tegakan Jati

Dalam penelitian ini, tinggi tegakan Jati total yakni dari permukaan tanah hingga ujung tertinggi, dimana alat yang digunakan adalah clinometer. Sedangkan diameter diukur dengan menggunakan pita ukur keliling. Untuk lebih jelas dapat dilihat dengan persamaan dibawah ini:

\section{Tinngi Tegakan $=\mathbf{C}+\mathbf{B}, \operatorname{dimana} \mathbf{C}=\operatorname{Tan} \alpha \times \mathbf{A}$ \\ Diameter Tegakan $=\mathrm{K} / \boldsymbol{\pi}$}

\section{Potensi Biomassa Tersimpan}

Dalam penelitian ini, biomassa yang dihitung adalah biomassa yang berada diatas permukaan tanah yang diperoleh dengan pendekatan pengukuran diameter dan 
tinggi pohon. Total biomassa tegakan Jati per luasan plot contoh diperoleh dengan menjumlahkan biomassa individu tegakan (Hairiah dan Rahayu, 2007) seperti pada formula berikut :

$$
\begin{aligned}
\mathbf{Y} & =\mathbf{0 , 1 1} \times \boldsymbol{\rho} \times \mathbf{D}^{\mathbf{2 , 6 2}} \\
\text { Dimana }: Y & =\text { Biomassa total }(\mathrm{g}) \\
\rho & =\text { Berat jenis kayu }\left(\mathrm{gr} / \mathrm{cm}^{3}\right)\left(\mathrm{BJ} \text { pohon Jati }=0,705 \mathrm{~g} / \mathrm{cm}^{3}\right), \\
D & =\text { Diameter pohon }(\mathrm{cm})
\end{aligned}
$$

\section{Estimasi sekuestrasi Karbon}

Nilai biomassa tegakan Jati yang telah diketahui dapat digunakan untuk mengestimasi stok karbon yang tersimpan dalam tegakan Jati karena $47 \%$ biomassa tersusun oleh karbon (Hairiyah dan Rahayu, 2011) sehingga dari hasil perhitungan biomassa dapat diubah dalam bentuk karbon $(\mathrm{kg})$ melalui proses perkalian nilai biomassa dengan faktor konversi sebesar 0,47 (IPCC, 2006).

$$
\mathrm{C}=\mathbf{0 , 4 7} \times \mathrm{B}
$$

Dimana : $\mathrm{C}=$ Sekuestrasi karbon $(\mathrm{g})$

$$
\mathrm{B}=\text { Nilai biomassa }(\mathrm{g})
$$

\section{Estimasi sekuestrasi Karbondioksida $\left(\mathrm{CO}_{2}\right)$}

Menurut Manuri, dkk (2011), nilai karbon tersimpan yang diperoleh dikalikan dengan 3,67 untuk mengetahui estimasi besarnya sekuestrasi serapan $\mathrm{CO}_{2}$. Nilai 3,67 merupakan konstanta untuk mengkonversi karbon menjadi bentuk $\mathrm{CO}_{2}$. Nilai tersebut berasal dari rumus berikut (Astuti, 2012).

$$
\begin{aligned}
\text { Sekuestrasi } \mathrm{CO}_{2} & =\frac{\mathrm{MrCO}_{2}}{\text { Ar C }} \text { Kandungan } \mathrm{Cx} \mathbf{3 , 6 6 7} \\
\text { Dimana }: \mathrm{MrCO}_{2} & =\text { Berat molekul senyawa } \mathrm{CO}_{2}(44) \\
\mathrm{ArC} & =\text { Berat molekul realtie atom } \mathrm{C}(12) .
\end{aligned}
$$

\section{HASIL DAN PEMBAHASAN}

\section{Biomassa Tegakan Jati (Tectona grandis L.) Di Areal Penghijauan Kabupaten Sorong}

Biomassa merupakan banyaknya materi organik yang tersimpan dalam pohon. Distribusi biomassa pada tiap komponen pohon menunjukkan banyaknya hasil fotosintesis pohon yang disimpan oleh tanaman. Biomassa menggambarkan jumlah karbon yang dapat dilepas ke atmosfer sebagai karbondioksida ketika hutan mengalami kerusakan. Sebaliknya, melalui pendugaan dapat dilakukan estimasi karbondioksida yang dapat diambil dari atmosfer dengan cara melakukan penghijauan maupun reboisasi (Brown, 1997).

Berdasarkan hasil penelitian dan pengukuran diameter dan tinggi pohon dari tegakan Jati (Tectona grandis L.) di Areal Penghijauan Kabupaten Sorong diperoleh data seperti terlihat pada Tabel 1 dan gambar 1. 
Tabel 1. Hasil Pengukuran Diameter Dan Tinggi Pohon pada Tegakan Jati di Areal Penghijauan Kabupaten Sorong

\begin{tabular}{ccccc}
\hline No. & $\begin{array}{c}\text { Petak/Plot } \\
\text { Pengamatan }\end{array}$ & Jumlah Pohon & $\begin{array}{c}\text { Dbh Rata-Rata } \\
(\mathbf{C m})\end{array}$ & $\begin{array}{c}\text { Tinggi Rata-Rata } \\
(\mathbf{M})\end{array}$ \\
\hline 1. & I & 43 & 16 & 6,28 \\
2. & II & 42 & 17 & 5,84 \\
3. & III & 44 & 19 & 7.15 \\
4. & IV & 39 & 15 & 6,72 \\
5. & V & 42 & 16 & 6,83 \\
\hline & Total & $\mathbf{2 1 0}$ & $\mathbf{8 3}$ & $\mathbf{3 2 , 8 2}$ \\
\hline & Rata-Rata & $\mathbf{4 2}$ & $\mathbf{1 6 , 6}$ & $\mathbf{6 , 5 6}$ \\
\hline
\end{tabular}

Sumber : Data terolah, 2018

Jumlah Pohon dan Diamater Pohon Jati di Areal Penghijauan Kabupaten Sorong

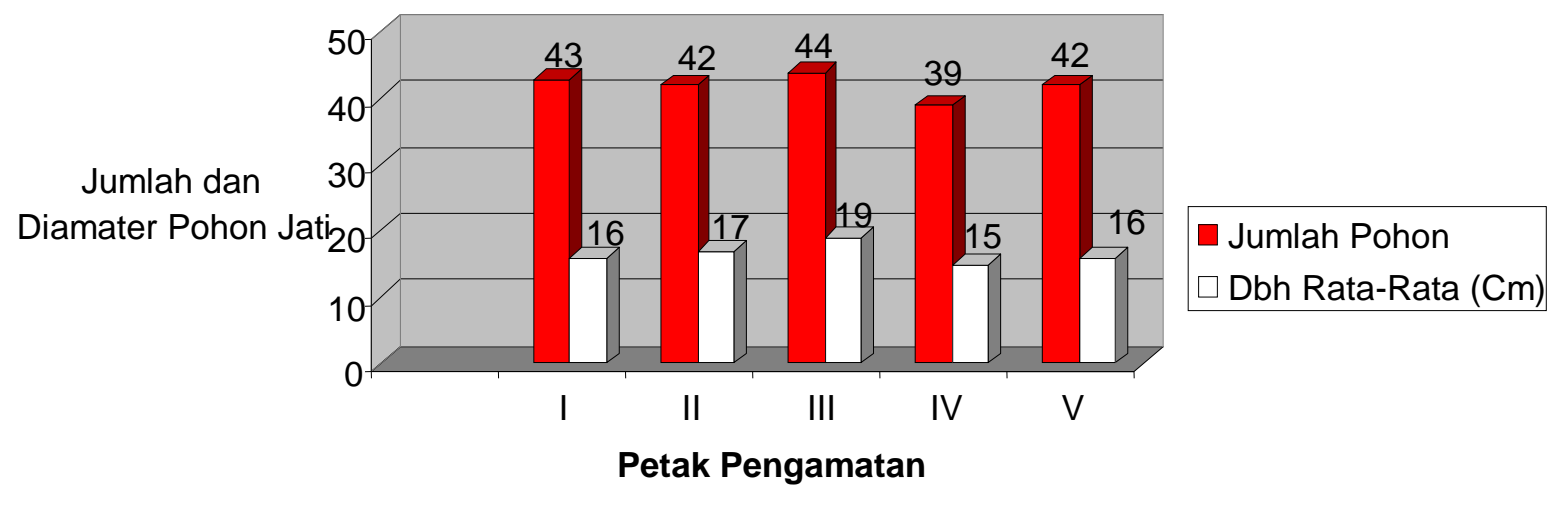

Gambar 1. Jumlah dan Diameter Pohon Jati di Areal Penghijauan Kabupaten Sorong

Berdasarkan hasil penelitian bahwa dari 5 petak percobaan penelitian yang dilakukan, terlihat jumlah tegakan pohon Jati sebanyak 210 dengan rata-rata per petak sebanyak 42 pohon. Dari data pengukuran diameter dan tinggi pohon Jati dipreoleh rata-rata diameter pohon di areal ini adalah $16,60 \mathrm{~cm}$ sedangkan tingginya rata-rata adalah 6,56 m. Data diamater tersebut diatas digunakan untuk mengetahui jumlah biomassa yang terkandung pada setiap pohon Jati, karena diameter pohon merupakan faktor yang berpengaruh terhadap jumlah biomassa yang terkandung maupun jumlah karbon yang tersimpan pada tegakan Jati.

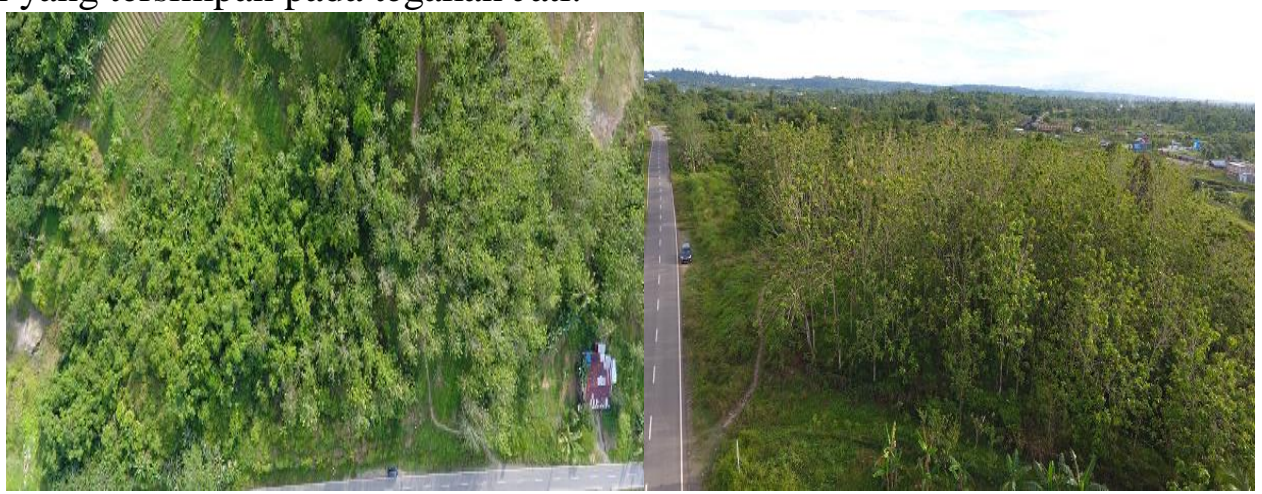

Gambar 2. Areal Penghijauan Hutan Jati Kabupaten Sorong 
Nilai total biomassa dari tegakan Jati digunakan persamaan allometrik, dengan mencari hubungan tinggi pohon dan diameter pohon setinggi dada, akan tetapi persamaan allometrik yang digunakan dengan melakukan pendekatan pada persamaan yang telah didapat pada penelitian sebelumnya yakni penelitiaan pohon Jati maupun persamaan pohon lainnya.

Persamaan allometrik merupakan model matematika sederhana yang menyatakan korelasi antara biomassa pohon dengan komponen yang dapat diukur seperti diameter pohon, yang mengacu dengan model persamaan allometrik pada metode penelitian diperoleh jumlah kandungan biomassa sebagaimana tersaji pada tabel 2 di bawah ini:

Tabel 2. Biomassa Tegakan Jati per Satuan Luas

\begin{tabular}{ccccc}
\hline No. & Petak & $\begin{array}{c}\text { Jumlah Pohon } \\
(\mathbf{n})\end{array}$ & $\begin{array}{c}\text { Dbh Rata-Rata } \\
(\mathbf{c m})\end{array}$ & $\begin{array}{c}\text { Biomassa } \\
(\mathbf{g})\end{array}$ \\
\hline 1. & I & 43 & 16 & $4.762,68$ \\
2. & II & 42 & 17 & $5.453,86$ \\
3. & III & 44 & 19 & 7.645 .00 \\
4. & IV & 39 & 15 & $3.647,67$ \\
5. & V & 42 & 16 & $4.651,92$ \\
\hline \multicolumn{2}{r}{ Total } & $\mathbf{2 1 0}$ & $\mathbf{8 3}$ & $\mathbf{2 6 . 1 6 1 , 1 3}$ \\
\hline \multicolumn{2}{c}{ Rata-Rata } & $\mathbf{4 2}$ & $\mathbf{1 6 , 6}$ & $\mathbf{5 . 2 3 2 , 2 3}$ \\
\hline
\end{tabular}

Sumber : Data terolah, 2018

BJ pohon Jati $=0,705 \mathrm{~g} / \mathrm{cm}^{3}$,

Nilai potensi biomassa yang terkandung pada tegakan Jati yang telah diperoleh kemudian dimasukkan dalam persamaan Allometrik. Berdasarkan data diatas menunjukkan bahwa berat biomassa dari hasil perhitungan 5 petak pengamatan (luasan $0,2 \mathrm{ha}$ ) pada tabel diatas tersebut adalah $26.161,13 \mathrm{~g}$. Sehingga untuk mengetahui berat biomassa dalam luasan satu hektar maka hasil dari perhitungan setiap plot dikalikan lima, dengan asumsi rata-rata jumlah tegakan Jati sebanyak 1.100 tegakan per hektar maka jumlah biomassa terkandung dalam tegakan pohon Jati adalah sebesar 130.805,65 g/ha.

Hasil penelitian juga terlihat bahwa potensi kandungan biomassa pada tegakan Jati pada pengukuran beberapa plot sampel, mempunyai jumlah pohon sampel yang hampir sama dikarenakan pengaturan jarak tanam dan tahun tanam yang sama serta tinggi tanaman awal ditanam hampir dikatakan sama.

Pertambahan diameter suatu dimensi batang akan menentukan besarnya karbon yang terserap dalam suatu tegakan. Pertambahan diameter merupakan dari hasil fotosintesis untuk pertumbuhan diameter batang (riap). Haygreen dan Bowyer (1996) menyatakan bahwa dengan bertambahnya umur suatu pohon melalui pembentukan dan pembelahan sel serta pembesaran sel berulang-ulang membentuk sel-sel baru yang meristematik. Selama pertumbuhan dan perkembangan sel melalui pembesaran diameter batang, cabang serta memperbanyak jumlah bagian-bagian pohon lainnya dimana karbon yang berasal dari $\mathrm{CO}_{2}$ tersebut diambil oleh pohom dan disimpan dalam bentuk biomassa. Dengan bertambahnya diameter pohon maka kemampuan pohon menyimpan karbon bebas dari udara semakin tinggi.

Pohon dengan ukuran diameter yang masih kecil proses peningkatan karbon dan biomassa yang relatif lambat yang selanjutnya akan semakin cepat seiring berambahnya diameter. Rahayu et al. ( 2007) menyatakan bahwa perbedaan jumlah biomassa suatu 
pohon dipengaruhi oleh kerapatan vegetasi, keragaman ukuran diameternya dan sebaran berat jenis vegetasinya, dimana penggunaan lahan yang terdiri dari pohon dengan jenis yang mempunyai nilai kerapatan kayu tinggi, biomassanya akan lebih besar bila dibandingkan dengan lahan yang mempunyai jenis dengan nilai kerapatan kayu rendah. Tipe hutan tanaman dengan komposisi jenis pohon dengan berat jenis yang besar akan mempunyai potensi simpanan yang cenderung lebih besar daripada tipe hutan tanaman dengan kerapatan tinggi tetapi jenis pohon dengan berat jenis yang rendah

Biomassa pohon terbesar pada pohon yang memiliki diameter paling besar dan tinggi. Hal ini disebabkan biomassa berkaitan erat dengan fotosintesis, laju pertambahan suatu pohon disebabkan karena pohon menyerap $\mathrm{CO}_{2}$ dari udara dan mengubahnya menjadi senyawa lignin dan selulosa dari proses fotosintesis. Biomassa pada setiap dimensi pohon tersebut meningkat secara proporsional dengan semakin besarnya diameter pohon sehingga biomassa pada tiap bagian pohon mempunyai hubungan dengan diameter pohon.

Jumlah biomassa yang terkandung pada tegakan hutan Jati ini merupakan gambaran produktifitas dari tegakan Jati di kawasan tersebut, karena pada prinsipnya pembentukan bagian dimensi pohon berkorelasi dengan produktifitas biomassanya, dimana semakin lama umur pohon akan semakin besar pula biomassa yang dihasilkan (Walpone, 1993). Biomassa yang dihasilkan pada setiap jenis pohon juga berbeda-beda yang akan mempengaruhi perbedaan dari kualitas kayu, jumlah biomassa yang dihasilkan oleh tanaman tahunan juga lebih besar daripada tanaman semusim karena pada tanaman tahunan pada umumnya memiliki siklus hidup yang panjang seperti pada vegetasi hutan, begitu juga dengan vegetasi yang ada pada hutan tanaman Jati ini sehingga akumulasi biomassa juga semakin besar.

Berdasarkan organ daun, indeks luas daun pohon Jati lebih besar dibandingkan dengan luas daun pohon lainnya. Hal inilah yang mungkin menjadikan pohon jati memiliki produktifitas lebih tinggi dibandingkan pohon lain. Luas daun berpengaruh pada kecepatan laju fotosintesis dengan bentuk daun tegakan Jati yang lebih lebar maka akan semakin cepat pula dalam proses fotosintesisnya. Hal ini linier dengan Robertus (2010), yang menyatakan bahwa sekuestrasi karbon oleh pohon juga dipengaruhi oleh indeks luas penampang daunnya, yang berhubungan erat dengan proses fotosintesis. Muhammad Isa (2009), menyatakan bahwa biomassa pohon dinyatakan sebagai Berat Kering (BK) bahan yang nilainya berbeda-beda dari setiap pohon, selain dipengaruhi oleh faktor luar seperti intensitas cahaya, ketersediaan air dan unsur hara. Faktor lain yang juga mempengaruhi yakni sifat dari pohon itu sendiri karena biomassa terbentuk selama masa pertumbuhan yang membentuk struktur dan organ pohon yang sebagian besar terdiri dari molekul lignin dan selulosa. Faktor-faktor tersebut sangat berpengaruh terhadap laju pembentukan biomassa pada tegakan pohon. Faktor-faktor tersebut berkaitan dengan banyaknya biomassa yang terkandung pada tegakan Jati karena akan tumbuh dengan baik pada daerah dengan tipe curah hujan C-F Schmidt and Ferguson dengan curah hujan rata-rata 1.200 sampai dengan $2.000 \mathrm{~mm}$ per tahun dan umumnya tumbuh pada dataran rendah yakni pada ketinggian 0 - 700 m.dpl (Martawijaya, dkk., 1981).

Perbedaan pendugaan estimasi jumlah kandungan biomassa pada penelitian ini juga dipengaruhi oleh laju produksi biomassa yang berbeda dari setiap pohon Jati, dimana menurut (Niinemets, 2007) laju produksi biomassa (bahan kering) tanaman atau pohon sangat bergantung dari laju akumulasi biomassa harian dikurangi kehilangan biomassa oleh proses fisiologi seperti respirasi (Niinemets, 2007). Selain itu, akumulasi 
biomassa suatu tanaman atau pohon juga dipengaruhi oleh umur, ketersediaan unsur hara, tanah, dan iklim setempat (Brown, 1997). Semakin tinggi dan besar suatu pohon atau tanaman serta semakin tua umur tanaman atau pohon tersebut, maka cadangan karbon semakin meningkat. Biomassa yang terkandung dalam suatu bagian organ tanaman atau pohon dipengaruhi oleh kandungan karbohidrat yang diperoleh melalui hasil fotosintesis daun. Hasil fotosintesa pada organ daun suatu tanaman atau pohon akan mengahasilkan karbohidrat yang akan ditranslokasikan ke seluruh organ tanaman atau pohon (batang, ranting dan daun) (Gust, 2011). Banyaknya biomassa yang tersimpang pada suatu tegakan atau pohon berhubungan dengan karbon yang tersimpan semakin besar biomassa yang terkandung dalam suatu tegakan pohon maka akan semakin besar pula karbon yang tersimpan. Karbon yang tersimpan pada tegakan pohon berkaitan dengan siklus karbon karena karbon yang seharusnya lepas ke atmosfer dan menjadi $\mathrm{CO}_{2}$ mampu disimpan pada tegakan pohon, dengan demikian maka potensi bertambahnya GK di atmosfer dapat dikurangi. Zebua (2008) menyatakan bahwa jumlah biomassa suatu tegakan hutan sangat dipengaruhi oleh umur, komposisi dan struktur tegakan hutan.

Hasil penelitian menyatakan bahwa makin lama umur pohon tersebut, maka makin besar pula nilai biomassa yang tersimpan, dimana dalam penelitian ini umur pohon Jati sangat berpengaruh pada proses penyerapan karbon dan biomassa. Bertambahnya umur pohon berpengaruh terhadap volume batang, dimana pertambahan volume ini menunjukkan bahwa biomassa yang terkandung semakin besar pula. Umur tegakan pohon Jati berkisar antara 5 - 10 tahun dan rata-rata diameter pohon adalah sebesar 16,60 cm. Penelitian Tyas., dkk. (2005) mengungkapkan bahwa umur tegakan Jati berkorelasi positif dengan tingkat pengurangan emisi gas karbon.

Pada penelitian ini tegakan pohon Jati bersifat bersifat sejenis atau homogen. Kehomogenan tegakan Jati tersebut menyebabkan tidak ada perbedaan jumlah biomassa dan karbon yang tersimpan karena tegakan yang bervariasi mempunyai daya serap karbon yang hampir sama.

Walpone (1993) mengungkapkan bahwa jumlah biomassa berhubungan erat dengan dimensi (tinggi dan diameter) pohon. Biomassa pada setiap bagian pohon meningkat secara proporsional seiring dengan meningkatnya dimensi pohon tersebut, sehingga biomassa pada setiap bagian pohon mempunyai hubungan dengan diameter pohon (Catur dan Sidiyasa, 2001). Peningkatan jumlah karbon sejalan dengan peningkatan biomassanya, semakin tinggi jumlah biomassanya semakin tinggi pula jumlah karbon yang tersimpan. Prosentase kandungan karbon dalam bahan organik adalah $47 \%$ dari jumlah biomassanya (Hairiyah dan Rahayu, 2007). Melihat tegakan Jati yang ada pada lokasi penelitian jumlah biomassa yang dihasilkan masih bisa meningkat mengingat tegakan Jati pada lokasi penelitian ini masih berproduksi. Selain itu tegakan di lokasi penelitian ini adalah tanaman tahunan yang berumur panjang sehingga semakin lama maka proses pembentukan biomassa juga meningkat. Seperti yang diketahui, biomassa berhubungan dengan proses fotosintesa, dimana kandungan biomassa bertambah karena menyerap $\mathrm{CO}_{2}$ dari udara dan mengubahnya menjadi senyawa organik melalui fotosintesa..

\section{Estimasi Sekuestrasi Karbon}

Nilai sekustrasi karbon tersimpan ditentukan dengan pengukuran biomassa pohon. Sekuestrasi karbon tersimpan merupakan $47 \%$ dari biomassa pohon yang diukur 
(Hairiah, 2007). Biomasa pohon (dalam berat kering) dihitung menggunakan "allometric equation" berdasarkan pada diameter batang setinggi $1,3 \mathrm{~m}$ di atas permukaan tanah (dalam $\mathrm{cm}$ ). Jumlah biomassa yang tersimpan pada tegakan pohon dapat digunakan untuk mengetahui jumlah karbon yang tersimpan pada tegakan pohon, karena $47 \%$ biomassa adalah berbentuk karbon (Brown,S. And Lugo, A.E., 1984).

Berdasarkan teori tersebut dan dengan memperhatikan biomassa dari tegakan Jati di Areal Penghijauan Kabupaten Sorong, maka nilai sekuestrasi karbon pada Tegakan Jati yang tersimpan dapat dilihat pada Tabel 3 berikut ini :

Tabel 3. Biomassa Tegakan dan Sekuestrasi Karbon pada Tegakan Jati di Areal Penghijauan Kabupaten Sorong per Satuan Luas

\begin{tabular}{|c|c|c|c|}
\hline No. & Petak & Biomassa (B) (g) & Sekuestrasi Karbon (C) (g) \\
\hline 1. & $\mathrm{I}$ & $4.762,68$ & $2.238,46$ \\
\hline 2. & II & $5.453,86$ & $2.563,31$ \\
\hline 3. & III & 7.645 .00 & $3.593,15$ \\
\hline 4. & IV & $3.647,67$ & $1.714,41$ \\
\hline 5. & V & $4.651,92$ & $2.186,40$ \\
\hline \multicolumn{2}{|c|}{ Total } & $26.161,13$ & $12.295,73$ \\
\hline \multicolumn{2}{|c|}{ Rata-Rata } & $5.232,23$ & $2.459,15$ \\
\hline
\end{tabular}

Sumber : Data terolah, 2018

Berdasarkan hasil analisis data pada tabel 3 diatas menunjukkan bahwa estimasi atau perkiraan sekuestrasi karbon pada tegakan Jati di Areal penghijauan Kabupaten Sorong berjumlah $12.295,73 \mathrm{~g}$, sekuestrasi karbon tertinggi terdapat pada plot atau petak pengamatan III yaitu sebesar 3.593,15 dan terendah pada petak IV yaitu sebesar 1.714,41. Kondisi ini disebabkan karena perbedaan jumlah tegakan Jati dan ukuran diameter. Menurut Brown (1994), banwa 47\% dari biomassa adalah berbentuk karbon, berdasarkan hasil penelitian karbon yang tersimpan paling banyak ada pada plot III, mengingat pada plot tersebut didominasi oleh tegakan Jati yang diameter pohonnya mencapai $19 \mathrm{~cm}$, selain itu tegakan Jati pada plot ini sudah berumur lebih dari 5 tahun. Selain hal diatas, kondisi di lapangan pada plot III ini merupakan plot yang berdekatan dengan jalan raya sehingga buangan karbon dari berbagai kendaraan banyak diserap oleh pohon di plot III ini lebih besar jika dibandingkan dengan plot contoh lainnya. Selain itu, menurut Robertus (2010) menyatakan bahwa penyerapan karbon oleh tanaman atau pohon juga dipengaruhi indeks luas penampang daunnya, hubungan ini erat dengan proses fotosintesis. karena secara fisik luas daun dari pohon Jati lebih besar dibandingkan dengan luas dari daun pohon lainnya. Jumlah karbon yang terkandung pada tegakan jati di Areal Penghijauan Kabupaten Sorong sebesar 61.478,65 g/ha hasil ini diperoleh dari jumlah karbon pada setiap plot contoh dikalikan lima karena ukuran plot pengamatan hanya seluas 20 × $20 \mathrm{~m} 2$ sebanyak 5 petak.

Dalam konteks teori ilmu tumbuhan menggunakan $\mathrm{CO}_{2}$ dan air untuk menghasilkan glukosa dan oksigen sebagai sumber energinya, energi untuk proses ini berasal dari fotosintesis yaitu proses produksi karbohidrat yang berasal dari bahan oanorganik melalui transformasi enegi matahari menjadi energi kimia. Pengukuran potensi penyerapan gas $\mathrm{CO}_{2}$ dilakukan dengan menggunakan perbandingan berat masa gas $\mathrm{CO}_{2}$ dengan berat masa atom C. Menurut Rahayu et al (2007), jumlah karbon tersimpan dalam suatu pengunaan lahan dipengaruhi oleh jumlah kerapatan vegetasinya, 
semakin rapat vegetasi pada lahan tersebut maka semakin banyak jumlah karbon yang tersimpan.

\section{Estimasi Sekuestrasi Karbondiokida $\left(\mathrm{CO}_{2}\right)$}

Biomassa berhubungan dengan proses fotosintesa, pertamnahan biomassa karena tanaman atau pohon menyerap $\mathrm{CO}_{2}$ dari udara dan merubahnya menjadi senyawa organik melalui fotosintesa. Hasil fotosintesis tersebut dimanfaatkan oleh tanaman atau pohon dalam pertumbuhan dan perkembangan baik kearah horizontal dan vertikal sehingga ukuran diameter dan tinggi tanaman akan semakin bertambah. Menurut (Lugo dan Snedaker 1974, dalam Handoko 2007) biomassa tersusun terutama oleh senyawa karbohidrat yang terdiri dari unsur karbon dioksida, hidrogen, dan oksigen. Besarnya biomassa tegakan dipengaruhi oleh umur tegakan, komposisi, dan struktur tegakan.

Berdasarkan hasil penelitian menunjukkan bahwa sekuestrasi karbondioksida tertinggi pada tegakan Jati areal penghijauan Kabupaten Sorong terdapat pada petak pengamatan III yaitu sebesar 13.186,86 g, sedangkan sekuestrasi karbon terendah terdapat pada petak pengamatan IV yaitu sebesar $6.291,88 \mathrm{~g}$, lebih lengkapnya dapat dilihat pada tabel berikut ini.

Tabel 4. Estimasi Sekuestrasi Karbondioksida $\left(\mathrm{CO}_{2}\right)$

\begin{tabular}{cccc}
\hline No. & Petak & $\begin{array}{c}\text { Sekuestrasi Karbon }(\mathbf{C}) \\
(\mathbf{g})\end{array}$ & $\begin{array}{c}\text { Sekuestrasi Karbondioksida } \\
\left(\mathbf{C O}_{2}\right)(\mathrm{g})\end{array}$ \\
\hline $\boldsymbol{I}$ & $\mathbf{2}$ & $\mathbf{3}$ & $\mathbf{4}$ \\
\hline 1. & I & $2.238,46$ & $8.215,15$ \\
2. & II & $2.563,31$ & $9.407,35$ \\
3. & III & $3.593,15$ & $13.186,86$ \\
4. & IV & $1.714,41$ & $6.291,88$ \\
5. & V & $2.186,40$ & $8.024,09$ \\
\hline \multicolumn{2}{r}{ Total } & $\mathbf{1 2 . 2 9 5 , 7 3}$ & $\mathbf{4 5 . 1 2 5 , 3 3}$ \\
\hline \multicolumn{2}{r}{ Rata-Rata } & $\mathbf{2 . 4 5 9 , 1 5}$ & $\mathbf{9 . 0 2 5 , 0 7}$ \\
\hline
\end{tabular}

Sumber : Data terolah, 2018

Dari tabel di atas dapat dilihat bahwa jumlah stok sekuestrasi karbondioksida yang terkandung pada tegakan pohon Jati adalah sebesar 12.295,73 g, dengan demikian maka tegakan Jati mempunyai potensi serapan karbondioksida sebesar 45.125,33 g atau 225.626,65 g/hektar. Hal itu berarti tegakan jati mempunyai potensi serapan karbondioksida cukup besar meskipun masih jauh lebih kecil dibandingkan dengan hutan lindung atau hutan sekunder bekas kebakaran hutan. Diduga jumlah serapan karbon ini dipengaruhi oleh kondisi iklim, topogafi jenis vegetasi dan kerapatan vegetasinya. Tingkat keterserapan karbon yang besar pada umumnya terjadi pada kawasan hutan dengan tingkat kesuburan yang tinggi dan curah hujan cukup, dan pada tanaman yang cepat tumbuh.

Dari hasil penelitian ini dapat diketahui apabila keberadaan tegakan Jati di Areal Penghijauan Kabupaten Sorong ini tidak ada, maka karbondioksida sebesar 225.626,65 g karbon akan tetap berada bebas di atmosfer. Akibatnya kandungan karbon di atmosfer akan semakin meningkat yang akhirnya akan berpengaruh lebih besar terhadap pemanasan suhu di wilayah Kabupaten Sorong. Salah satu faktor yang dapat mengurangi jumlah akumulasi $\mathrm{CO}_{2}$ melalui proses fotosintesis, dimana penimbunan dan pengendapan karbon sering disebut sebagai rosot karbon. Proses penyimpanan karbon 
dalam tanaman atau pohon yang sedang tumbuh disebut sebagai sekuestrasi karbon (carbon sequestration).

Serapan $\mathrm{CO}_{2}$ oleh tegakan Jati ini menggambarkan kemampuan vegetasi yang berada di luar kawasan hutan ini untuk memfiksasi $\mathrm{CO}_{2}$ yang kemudian disimpan dalam bentuk cadangan karbon pada tegakan pohon Jati tersebut. Tegakan Jati yang ditanam sebagai tanaman penghijauan kota mempunyai kemampuan menyerap karbon dengan jumlah yang cukup besar. Di samping itu, tanaman ini mempunyai sistem perakaran tunggang yang kuat dan tahan terhadap gangguan fisik. Jika tegakan Jati di Areal Penghijauan Kabupaten Sorong dipertahankan keberadaannya atau ditambah penenamannya maka akan memberikan kontribusi terhadap keselamatan lingkungan perkotaan dari ancaman pencemaran udara yang dihasilkan oleh kendaraan bermotor serta limbah rumah tangga dan disamping bentuk-bentuk polutan lainnya yang dapat mengemisikan gas-gas tertentu di udara.

Melalui proses fotosintesis, $\mathrm{CO}_{2}$ di udara diserap oleh tanaman dan dengan bantuan sinar matahari kemudian diubah menjadi karbohidrat untuk selanjutnya didistribusikan keseluruh tubuh tanaman dan ditimbun dalam bentuk daun, batang, cabang, buah, dan bunga (Hairiah dan Rahayu 2007). Walaupun aktifitas fotosintesis terjadi di daun, namun distribusi hasil fotosintesis terbesar digunakan untuk pertumbuhan batang. Batang umumnya memiliki zat penyusun kayu yang lebih baik dibandingkan dengan bagian pohon lainnya. Zat penyusun kayu tersebut menyebabkan bagian rongga sel pada batang banyak tersusun oleh komponen penyusun kayu dibanding air, sehingga bobot biomassa batang akan menjadi lebih besar.

Tegakan atau pohon berumur panjang seperti Jati yang tumbuh di hutan maupun di kebun campuran merupakan tempat penimbunan atau penyimpanan $\mathrm{C}$ yang jauh lebih besar dari pada tanaman semusim karena pada tanaman tahunan seperti di tegakan Jati di lokasi penghijauan Kabupaten Sorong ini memiliki siklus hidup yang lebih panjang sedangkan pada tanaman semusim lepasnya karbon akan lebih cepat mengingat setelah tanaman tidak berproduksi akan di ganti dengan tanaman yang baru. Oleh karena itu, tegakan Jati di Areal Penghijauan Kabupaten Sorong dengan keragaman jenis pepohonan berumur panjang dan seresah yang banyak merupakan gudang penyimpan $\mathrm{C}$ tertinggi (baik di atas maupun di dalam tanah). Jika hutan diubah fungsinya menjadi lahan pertanian, perkebunan maupun ladang penggembalaan maka jumlah karbon tersimpan akan berkurang apalagi di konversi menjadi areal pemukiman (Kurniatun $\mathrm{H}$ dan Rahayu, 2007).

Karbon yang terdapat bebas di atmosfer diserap dan disimpan dalam tubuh tumbuhan sehingga karbon sebagai gas rumah kaca sebagai penyebab terjadinya pemanasan global dapat dikendalikan. Pemanasan global berhubungan dengan akumulasi berbagai gas yang ada di atmosfer. Salah satu gas yang menyebabkan terjadinya pemanasan global adalah karbondioksida $\left(\mathrm{CO}_{2}\right)$. Akumulasi karbon di atmosfer akan menimbulkan efek rumah kaca, akibat terperangkapnya gelombang pendek sinar matahari, sehingga meningkatkan suhu atmosfer bumi. Selain akibat tersebut, intensitas Efek Rumah Kaca (ERK) akan ikut naik dan menyebabkan naiknya suhu permukaan bumi (Soemarwoto, 2001).

Pemanasan global berhubungan dengan akumulasi berbagai gas yang ada di atmosfer. Salah satu gas yang menyebabkan terjadinya pemanasan global adalah karbondioksida $\left(\mathrm{CO}_{2}\right)$. Aktivitas manusia seperti pembakaran bahan bakar atau hutan dapat mempengaruhi keseimbangan siklus karbon dan menyebabkan bertambahnya karbondioksida di atsmosfer. 
Dipermukaan bumi, karbon disimpan dalam biomassa pada setiap organisme misalnya pohon. Karbondioksida pada tanaman atau pohon tersimpang dalam bentuk karbon pada jaringan atau organ tubuh tanaman, jika tanaman itu mati maka karbon akan terurai, dimana kombinasi karbon dan oksigen akan membentuk karbon dioksida, sehingga apabila pohon ditebangi maka karbon dioksida akan kembali ke atsmosfer, dan karbon akan terlepas ke atmosfer sebagai karbon dioksida dan efek rumah kaca akan semakin nyata.

\section{KESIMPULAN}

1. Nilai biomassa yang terkandung pada pohon Jati di Areal Penghijauan Kabupaten Sorong menunujukkan bahwa berat biomassa dari hasil perhitungan 5 petak pengamatan (luasan 0,2 ha) adalah 26.161,13 g. Sehingga untuk mengetahui berat biomassa dalam luasan satu hektar maka hasil dari perhitungan setiap plot dikalikan lima, dengan asumsi rata-rata jumlah tegakan Jati sebanyak 1.100 tegakan per hektar maka biomassa yang terkandung dalam pohon Jati adalah sebesar 130.805,65 $\mathrm{g} / \mathrm{ha}$.

2. Estimasi atau perkiraan sekuestrasi karbon pada pohon Jati berjumlah $12.295,73 \mathrm{~g}$, sekuestrasi karbon tertinggi terdapat pada plot atau petak pengamatan III yaitu sebesar 3.593,15 dan terendah pada petak IV yaitu sebesar 1.714,41. Jumlah karbon yang terkandung pada tegakan jati sebesar 61.478,65 g/ha hasil ini diperoleh dari jumlah karbon pada setiap plot contoh dikalikan lima karena ukuran plot pengamatan hanya seluas $20 \times 20 \mathrm{~m}^{2}$ sebanyak 5 petak.

3. Jumlah stok sekuestrasi karbondioksida yang tersimpan pada pohon Jati adalah sebesar 12.295,73 g, dengan demikian maka tegakan Jati tersebut mempunyai potensi serapan karbondioksida sebesar 45.125,33 g atau 225.626,65 g/hektar..

\section{DAFTAR PUSTAKA}

Adinugroho, W. Catur dan K. Sidiyasa, 2006. Model Pendugaan Biomassa Pohon Mahoni (Swietenia macrophyla King) Di Atas Permukaan Tanah. Jurnal penelitian Hutan dan Konservasi alam Vol III No.1 hal: 103 - 117.

Anonim, 2011. Produksi Oksigen yang Dihasilkan Pohon. http://spkpdesacikanyere.blogspot.com/2012/01/produktivitas-oksigen-yangdihasilkan.html (Diakses 06 Maret 2018).

Asturi, W. I., 2016. Estimasi Stok Karbon Lahan Gambut Berdasarkan Stratifikasi Kedalaman Tanah di desa jabiren kabupaten Pulau Pisau. Skripsi. jurusan Biologi. institute Teknologi Sepuluh Novemver.

Brown, S. 1997. Estimasi Biomass and Biomass Change Of Tropical Forest. FAO forestry Paper. Roma.

Fachrul, M. F., 2006. Metode Sampling Bioekologi. Penerbit Bumi Aksara. Jakarta.

Hairiah K, Sitompul SM, Noordwijk MV, Cherly. 2001. Carbon Stock of Tropical Landuse System as Part of Global C Balance. Journal. Bogor

Hairiah K, Rahayu S. 2007. Pengukuran "Karbon Tersimpan” di Berbagai Macam enggunaan Lahan. Bogor. World Agroforestry Centre - ICRAF, SEA Regional Office, University of Brawijaya, Indonesia. 77p.

Lukito, M., 2010. Studi Inventarisasi Hutan tanaman Kayu Putih Dalam Menghasilkan Biomassa dan karbon hutan. Tesis Fakultas Kehutanan UGM. Tidak Di publikasikan 
Lukito, M., dan Rohmatiah, A., 2013. Estimasi Biomassa dan Karbon Tanaman Jati Umur 5 Tahun (Kasus Kawasan Hutan Tanaman Jati Unggul Nusantara Desa Krowe Kecamatan Lembeyen Kabupaten Magetan) Jurnal Agritek Vol. 14 Nomor 1 Maret 2013.

Lusiana B, Noordwijk MV, Rahayu S. editor. 2005. Carbon Stocks in Nunukan, East alimantan: A Spatial Monitoring and Modelling Approach. Report From the

Martawijaya A, Kartasujana I, Kadir K, Perwira SA. 1981. Atlas Kayu Indonesia. Jilid I. Bogor: Balai Penelitian dan Pengembangan Pertanian.

Pandiwijaya, D., 2011. Pendugaan Perubahan Cadangan Karbon Di Taman Nasional Gunung Merapi. Skripsi Departemen Konservasi Sumberdaya Hutan dan Ekowisata Fakultas Kehutanan Institut Pertanian Bogor. (tidak dipublikasikan).

Pandu Aji Asmoro, Jarot. 2010. POTENSI KARBON JENIS ENDEMIK PAPUA: Pometia pinnata J. R. Forst. \& G. Forst (Carbon Potency of Papua Endemic Spesies of Pometia pinnata J. R. Forst. \& G. Forst). JURNAL Penelitian Sosial dan Ekonomi Kehutanan Vol. 8 No. 4 Desember 2011, Hal. 299 - 305.

Rahayu, S, Lusiana, B, van Noordwijk, M 2007. Pendugaan Cadangan Karbon di Atas Permukaan Tanah pada Berbagai Sistem Penggunaan Lahan di Kabupaten Nunukan, Kalimantan Timur. Bogor: World Agroforestry Centre.

Simon, H. 2000. Hutan Jati dan Kemakmura: Problematika dan Strategi Pemacahannya. Bigraf Publishing. Yokyakarta

Siregar, E. B. M., 2005. Potensi Budidaya Jati. e-USU Repository@Univeritas Sumatera Utara.

Sumarna, Y. 2003. Budidaya Jati. PT. Penebar Swadaya. Jakarta.

Suryana, Y., 2001. Budidaya Jati. PT Penebar Swadaya. Bogor.

Sutaryo, D., 2009. Penghitungan Biomassa (Sebuah pengantar untuk studi karbon dan perdagangan karbon). Wetlands International Indonesia Programme. Bogor.

Tresnawan H, Rosalina U. 2002. Pendugaan Biomassa di Atas Tanah di Ekosistem utan Primer dan Hutan Bekas Tebangan (Studi Kasus Hutan Dusun Aro,Jambi). Jurnal Manajemen Hutan Tropika 8(1):15-29.

Uryu, Y. et al. 2008. Deforestasi, Degradasi Hutan, Hilangnya Keanekaragaman Hayati, dan Emisi CO2 di Riau, Sumatera, Indonesia. Laporan Teknik WWF-Indonesia, Jakarta, Indonesia 